\title{
ASPEK HUKUM PELAKSANAAN VAKSINASI COVID-19 DI INDONESIA
}

\author{
Stephanie PD* ${ }^{1}$, Enjelina $S^{2}$, Angelica $\mathrm{MF}^{3}$, Imelda Martinelli ${ }^{4}$ \\ ${ }^{1}$ Jurusan Hukum, Universitas Tarumanagara Jakarta \\ Email: stephanieuntar@gmail.com \\ ${ }^{2}$ Jurusan Hukum, Universitas Tarumanagara Jakarta \\ Email: Enjellsummerlee@gmail.com \\ ${ }^{3}$ Jurusan Hukum, Universitas Tarumanagara Jakarta \\ Email: jessicalicialim27@gmail.com \\ ${ }^{4}$ Jurusan Hukum, Universitas Tarumanagara Jakarta \\ Email: imeldam@fh.untar.ac.id
}

\begin{abstract}
The World Health Organization (WHO) defines the 2019-nCoV type of corona virus as a pandemic of a new type of disease spread throughout the world, this is not only a public health case, but will touch every sector. The COVID19 (cov-19) pandemic has resulted in an emergency for the healthy condition of the Indonesian people, so President Joko Widodo has issued Presidential Decree No. 11/2020. In "procuring vaccines and implementing vaccinations for the prevention of the COVID-19 pandemic" President Joko Widodo stipulates Presidential Decree No. 14/2021. In choosing health facilities and infrastructure independently \& responsibly, every human being has the right to choose according to his wishes, due to the pandemic conditions that concern the interests of the people and the state, so giving vaccinations is actually voluntary because emergency conditions can be forced. Although there is already a legal umbrella for Law No. 4/1984: "Infectious Disease Outbreaks" and Law No. 6/2018: "Health Quarantine", many in the field agree and vice versa on the implementation of vaccination in the community. The purpose of the study is to understand the nature of the administration of the corona vaccine according to the laws and regulations adopted and the factors that occur in society. Using a normative method with a qualitative approach. Giving vaccines to the community is forced. limited availability of vaccines; there are those who support there are those who are antipathy from the community regarding the implementation of vaccination; uneven distribution. The reason for the community's refusal to receive the Covid-19 vaccine is due to different trusts, this is supported by the lack of communication channels as well as the delivery of information that is not well targeted, the data on the type of vaccine is limited in information, the availability of the Covid-19 vaccine, as well as safe conditions. The government should fully support the Nusantara vaccine and the Merah Putih vaccine developed by Indonesian researchers.
\end{abstract}

Keywords: Vaccination, covid-19, pandemic, emergency.

ABSTRAK
World Health Organizatioan (WHO) mendefinisikan Virus corona jenis Virus 2019-nCoV sebagai pandemi jenis penyebaran penyakit baru keseluruh dunia, hal ini bukan hanya kasus kesehatan masyarakat, tapi akan menyentuh setiap sektor. Pandemi covid-19(cov-19) mengakibatkan kedaruratan kondisi sehat khalayak Indonesia, sehingga Presiden Joko Widodo menetapkan KeppresNo.11/2020. Dalam "pengadaan vaksin dan pelaksanaan vaksinasi untuk penanggulangan pandemi covid-19” Presiden Joko widodo menetapkan Perpres No.14/2021. Dalam memilih sarana juga prasarana kesehatan secara mandiri \& bertangggungjawab tiap manusia punya hak memilih sesuai dengan keinginannya, berhubung kondisi pandemi yang menyangkut kepentingan rakyat dan negara lebih diutamakan, jadi pemberian vaksinasi yang sebenaranya bersifat volunteer karena kondisi darurat bisa bersifat dipaksakan. Meskipun sudah ada payung hukum UU No.4/1984:"Wabah Penyakit Menular" serta UU No.6/2018:"Kekarantinaan Kesehatan", tapi dilapangan banyak yang setuju dan sebaliknya pada pelaksanaan vaksinasi dimasyarakat. Tujuan penelitian untuk memahami sifat dari pemberian vaksin corona menurut peraturan perundangan yang dianut dan faktor- faktor yang terjadi di masyarakat. Memakai metode normatif dengan pendekatan kualitatif. Pemberian vaksin kepada masyarakat bersifat memaksa. keterbatasan ketersedian vaksin; ada yang mendukung ada yang antipati dari masyarakat terkait pelaksanaan vaksinasi; penyaluran yang tidak merata. Alasan penolakan masyarakat dalam menerima vaksin Covid-19 dikarenakan adanya trust yang berbeda, hal ini didukung kurangnya alur komunikasi juga cara penyampaian informasi yang kurang tepat sasaran, data jenis vaksin terbatas informasinya, ketersediaan vaksinCov-19, juga syarat aman. Pemerintah selayaknya mendukung penuh vaksin Nusantara dan vaksin Merah Putih yang dikembangkan para peneliti Indonesia.

Kata Kunci: Vaksinasi, Covid-19, pandemi, kedaruratan. 


\section{PENDAHULUAN}

\section{Latar Belakang}

Covid-19 membuat dunia gempar dan menjadi pandemi mengerikan diseluruh dunia. Virus ini merupakan jenis virus baru dari Coronavirus, jenis virus RNA strain tunggal positif. Covid-19 disebarkan oleh SAR-CoV2, yang menyebabkan infeksi saluran pernafasan. Penyebaran virus corona tidak mengenal batas negara dan status sosial dalam masyarakat. Asal muasal virus belum terdeteksi hingga sekarang. Desember 2019 Wuhan sebagai titik nol, provinsi Hubei."Huanan seafood wholesale market"(China Selatan), pasar ini hewan liar dijual ilegal yang diduga sebagai titik nol dari penularan. (Harahap, 2020). Dengan semakin banyak yang terkena virus tersebut, akhirnya perpindahan terjadi antara manusia dengan manusia, diawal diyakini melalui perantara percikan ludah (droplet). 11 Maret 2020 World Health Organizatioan (WHO) mendefinisikan virus corona sebagai pandemi jenis penyebaran penyakit baru keseluruh dunia, hal ini bukan hanya kasus kesehatan masyarakat, tapi akan menyentuh setiap sektor. 2 maret 2020 berawal ditemukan kasus terjangkit virus pertama, dengan kasus pertama China berbeda 61 hari. Tertular saat berada di acara dansa Klub Paloma\&Amigos, Jakarta Selatan pada 14 Februari 2020 dari seorang warga negara Jepang yang tinggal di Malaysia. (Penularan virus corona di Indonesia besar kemungkinan dari kasus impor. (Jayani, 2020)

Pada tanggal 3 Mei 2020 Indonesia mengirim informasi 13 sampel "7 sampel dari lab. "Lembaga-Biologi-Molekuler(LBM)-Eijkman \& Universitas Airlangga sebanyak 6 sampel". Data perolehan rangkaian genom-SARS COV-2 ke "GISAID/Global Initiative on Sharing Avian Influenza Data". Hasilnya ada variasi genom-virus Indonesia dibanding kelompok dominan global yang sudah diidentifikasikan'. (Wuragil, 2020)

Salah satu asas-hukum adalah Lex specialis derogat legi generali, bermanfaat menyelesaikan benturan antara UU dengan substansi-pengaturan yang lebih luas dengan UU substansipengaturannya sempit. (Shidarta \& Petrus Lakonawa, 2018). Penanganan wabah diatur secara teknis dalam 2 perundangan yaitu: UU No.4/1984:"Wabah Penyakit Menular"(UU WPM) dan UU No.6/2018:"Kekarantinaan Kesehatan"(UU Kekarantinaan). Di Indonesia banyak korban covid-19 yang meninggal, Presiden Joko Widodo melalui Keppres No.11/2020:"Penetapan Kedaruratan Kesehatan Masyarakat Corona Virus Disease 2019 (covid-19)", disertai Perpres No.14/2021(perubahan atas Perpres No.99/2020):"Pengadaan Vaksin dan Pelaksanaan Vaksinasi Dalam Rangka Penanggulangan Pandemi Corona Virus Disease 2019 (Covid-19)".

Orang pertama Indonesia yang divaksin Presiden Joko Widodo (vaksin-Sinovac). Selanjutnya jajaran menteri dan pegawai pemerintah. Kemudian disusul kalangan masyarakat yang bersingungan langsung dengan penderita dan penanggulangan covid-19. Izin edar EUA 6 jenis vaksin yang tersedia di Indonesia Badan POM; 1) Vaksin Sinovac dari China 2) Vaksin Sinopharm dari China 3) Vaksin AstraZeneca dari Inggris 4) Vaksin Moderna dari Amerika Serikat 5) Vaksin Pfizer - BioNTech dari Amerika Serikat 6) Vaksin Novavax dari Amerika Serikat Data dari bea cukai, jumlah vaksin yang diimpor sampai 19 Juli 2021 total 143.666.040 dosis (Noveria. 2021).

Menurut Rahardjo norma merupakan sarana yang digunakan sosial masyarakat guna membenahi, membimbing, dan menuntun perilaku dalam berinteraksi antar masyarakat. Agar bisa berjalan dengan baik maka norma harus bisa memaksa dengan tujuan agar anggota masyarakat patuh. (Rahardjo, 2021). Ditingkat masyarakat pro dan kontra terkait pelaksanaan vaksinasi di Indonesia. Beberapa menanyakan perihal tingkat kemanjuran dan keberhasilan vaksinasi dengan dalil seperti tidak efektif karena bukan dari benih virus di Indonesia, isu konspirasi, bisnis nasional dan internasional, menimbulkan efek samping, sampai disinggung perihal efek kehalalannya. (Gandryani \& Hadi, (2021)). Sehingga perlu diteliti sifat pemberian vaksinasi covid-19 kepada masyarakat. Juga terdapat sejumlah pendapat tokoh masyarakat baik yang mendukung maupun yang tidak dalam pelaksanaan vaksinasi oleh pemerintah. Banyak faktor- 
faktor yang dihadapi dalam pelaksanaannya yaitu: terbatasnya pengadaan vaksin; penyaluran yang tidak merata; jumlah penyediaan akses kesehatan yang masih sangat terbatas, data informasi pendukung sangat terbatas, kendala pada alur komunikasi yang perlu diketahui masyarakat.

Sesuai uraian yang sudah dijelaskan diatas, diidentifikasikan permasalahan:

1. Bagaimanakah sifat pemberian vaksin kepada masyarakat menurut peraturan perundangundangan yang terkait?

2. Faktor-faktor apakah yang menjadi tantangan dalam menangani implementasi vaksin dalam masyarakat?

\section{METODE PENELITIAN}

Metode hukum normatif dasar dari penelitian, fokusnya data-sekunder (bahan hukum primer;sekunder;tersier) (Soekanto \& Mamudji,2021). Yang meliputi bahan-hukum-primer (perundang-undangan, peraturan presiden, keputusan presiden), bahan-hukum-sekunder (artikel, jurnal, buku) dan bahan-hukum-tersier (kamus). Sifat dari penelitian ini deskriptif dengan menggunakan pendekatan kualitatif untuk mendapatkan pemahaman gejala-gejala dari yang diteliti. Semua bahan hukum yang ada disortir, dirinci secara detail dan dijabarkan kemudian dihubungkan dengan aturan perundang-undangan terkait dengan yang diteliti.

\section{HASIL DAN PEMBAHASAN}

\section{Sifat Ketentuan Pemberian Vaksin Covid-19 Kepada Masyarakat.}

Pasal 1 Ayat(3) UUD'45:"Negara Indonesia adalah negara hukum”. Sehingga peraturan hukum sebagai pedoman dari perilaku institusi negara dan rakyatnya. Jadi berlaku "asas legalitas"(Due Process of Law) bahwa semua aktivitas pemerintah berdasarkan aturan UU yang absah dan tersurat. Perundang-undangan mendahului daripada perbuatan yang dilakukan. Juga berlaku HAM yang dilindungi secara hukum untuk ditegakkan secara adil. Dalam suatu negara HAM diabaikan, tidak ditindak secara adil bagi pelanggar HAM. Maka negara bukan negara hukum dalam pengertian sejatinya.(Mahkamah Konstitusi, 2016).

UUD 45 selain sebagai landasan konstitusional negara juga menjadi dasar hukum HAMIndonesia Pasal 28A \& 28J UUD'45, dijelaskan hak tiap warga Indonesia berhubungan dengan kesehatan Pasal 28H Ayat(1):"Setiap orang berhak hidup sejahtera lahir batin, bertempat tinggal, dan mendapatkan lingkungan hidup baik dan sehat serta berhak memperoleh pelayanan kesehatan". Tetapi dalam pelaksanaannya hak asasi ini dibatasi Pasal 28J Ayat(1):"Setiap orang wajib menghormati hak asasi manusia orang lain dalam tertib kehidupan bermasyarakat, berbangsa dan bernegara". Jadi kebebasan terbatas berlaku bagi warga negara Indonesia jika berhadapan dengan kepentingan masyarakat, berbangsa dan bernegara.

Pasal 1 Ayat(1) UU Nomor 36 Tahun 2009:“Kesehatan” (UUK) menyebutkan definisi kesehatan ialah "keadaan sehat,baik secara fisik,mental,spiritual maupun sosial yang memungkinkan setiap orang untuk hidup produktif secara sosial dan ekonomis". Hak warga negara dibidang kesehatan berdasar UU 36/2009 Pasal 5 Ayat(3) menjabarkan tiap warga punya hak swatantra \& bertanggungjawab memilih sarana dan prasarana kesehatannya. Ketentuan ini dipakai sejumlah pihak sebagai legitimasi yang menolak vaksin cov-19.

Kewajiban negara bagi kesehatan rakyatnya berdasar UUD'45 Pasal 34 Ayat(3):'Negara bertanggungjawab atas penyediaan fasilitas pelayanan kesehatan dan fasilitas pelayanan umum yang layak". Menunjukkan hak atas kesehatan termasuk fisik, mental dan spiritual dilindungi secara konstitusional. Hak asasi warga negara yang berkaitan dengan kesehatan, negara berkewajiban untuk memenuhinya. Dalam pengendalian pandemi pemerintah mengambil kebijakan guna melindungi dan memenuhi hak kesehatan warga negara. Dengan dasar hukum UUD'45 Pasal 22 Ayat(1) menyebutkan "kondisi kegentingan yang memaksa,Presiden berhak 
menetapkan peraturan pemerintah pengganti UU". Presiden Joko Widodo melalui Perpres No. 14/2021(perubahan atas Perpres No.99/2020) tentang "Pengadaan Vaksin dan Pelaksanaan Vaksinasi Dalam Rangka Penanggulangan Pandemi Corona Virus Disease 2019 (Covid-19)". Jika mengacu pada UUD'45 Pasal 22 Ayat(1) Presiden menetapkan peraturan pemerintah sebagai pengganti undang-undang, tetapi dalam kasus pandemi covid-19 yang memakan banyak korban di dunia. Presiden Jokowi menetapkan kebijaksanaan khusus dengan menetapkan Perpres $14 / 2021$.

Banyaknya korban covid-19 yang meninggal, pemerintah mengatur pelaksanaan "Pembatasan Sosial Berskala Besar" diatur Menkes dalam PP No.21/2020: "Pembatasan Sosial Berskala Besar Dalam Rangka Percepatan Penanganan Corona Virus Disease 2019 (Covid-19)”. Dapat dilakukan oleh Pemda berdasarkan persetujuan Menkes. Dengan siswa dan pegawai diliburkan, kerohanian juga sarana umum dibatasi, perizinan aktivitas hanya yang berhubungan dengan keperluan pokok khalayak meliputi pangan \& pendukungnya. PP No.21/2020 ditetapkan pemerintah untuk menjalankan UU Kekarantinaan dengan dasar Pasal 5 Ayat(2) yaitu Presiden menentukan peraturan pemerintah guna mewujudkan UU terkait. Presiden Jokowi juga mengeluarkan melalui Keppres No.11/2020 menetapkan status kedaruratan kesehatan Indonesia. Pasal 13B Perpres No.14/2021:"Setiap orang yang telah ditetapkan sebagai sasaran penerima vaksin covid-19, yang tidak mengikuti vaksinasi covid-19 sebagaimana dimaksud dalam Pasal 13A Ayat(2) dan menyebabkan terhalangnya pelaksanaan penanggulangan penyebaran covid-19, selain dikenakan sanksi sebagaimana dimaksud dalam Pasal 13A Ayat (4) dapat dikenakan sanksi sesuai ketentuan UU WPM".

Saat penulisan artikel tidak ada obat covid-19, cara penanggulangan yang dianggap paling efektif untuk menghentikan pandemi covid-19 dengan cara vaksinasi. Landasan hukum yang ditempuh Presiden Jokowi berawal dari Perpres No.14/2021 tentang "vaksinasi dan pengadaan vaksinasi" maka aturan UU yang berlaku adalah UU Kekarantinaan dan UU WPM. Sehingga bagi pihakpihak yang menggunakan UUK sebagai legitimasi untuk menolak vaksinasi covid-19 merupakan pelanggaran bagi yang tidak mengerti hukum, tapi bagi pihak yang mengerti hukum merupakan kejahatan karena dengan berlakunya UU WPM \& UU Kekarantinaan, maka UU No. 36/2009 dikesampingkan (tidak dapat dilaksanakan) disinilah Asas Lex specialis derogat legi generali berlaku.

Berdasar perundang-undangan terkait, khususnya UU WPM Pasal 5 Ayat(1)C. "Pencegahan dan Pengebalan". Maka sifat pemberian vaksinasi kepada masyarakat bersifat memaksa dan barang siapa menghalang-halangi upaya memangkas mata rantai penularan cov-19, menolak vaksinasi cov-19, maka orang tersebut bisa dikenakan sanksi sesuai dengan yang tercantum dalam Keppres No.14/2021 Pasal 13A Ayat(4):"setiap orang yang telah ditetapkan sebagai sasaran penerima vaksin cov-19 yang tidak mengikuti vaksinasi cov-19 sebagaimana dimaksud pada Ayat (2) dapat dikenakan sanksi administratif, berupa: a) penundaan atau penghentian pemberian jaminan sosial atau bantuan sosial; b) penundaan atau penghentian layanan administrasi pemerintah; dan/atau c) denda". Juga sanksi dari UU WPM Bab VI KETENTUAN PIDANA Pasal 14 Ayat(1) "Barangsiapa dengan sengaja menghalangi pelaksanaan penanggulangan wabah sebagaimana diatur dalam undang-undang ini, diancam dengan pidana penjara selama-lamanya 1 (satu) tahun dan/atau denda setinggi-tingginya Rp. 1.000.000,- (satu juta rupiah). Ayat(2) Barangsiapa karena kealpaannya mengakibatkan terhalangnya pelaksanaan penanggulangan wabah sebagaimana diatur dalam Undang-Undang ini, diancam dengan pidana kurungan selamalamanya 6 (enam) bulan dan/atau denda setinggi-tingginya Rp.500.000,- (lima ratus ribu rupiah). Ayat (3) Tindak pidana sebagaimana dimaksud dalam Ayat 1 adalah kejahatan dan tindak pidana sebagaimana dimaksud dalam Ayat 2 adalah pelanggaran”. 
Faktor-faktor Yang Dihadapi Dalam Menangani Pelaksanaan Vaksin Covid-19 Di Masyarakat.

Kebijakan pemerintah dalam melakukan vaksinasi corona telah ditetapkan sejak tahun 2020 dan pelaksaannya dimulai Januari 2021 banyak menghadapi tantangan dalam pelaksanaannya. Menurut Carolina satu diantara upaya pemerintah menanggulangi melebarnya pandemi yaitu dengan program Vaksin Cov-19 bagi 181.554 .465 penduduk Indonesia total vaksin yang diperlukan 426,8juta dosis-vaksin, namun banyak kendala dalam perwujudannya: a) Terbatasnya kesediaan vaksin Cov-19 disebabkan"PT.Bio Farma" mempunyai keterbatasan dana didalam pengadaan vaksin sebagai satu-satunya produsen vaksin; b) Dalam masyarakat terjadi dikotomi, ada yang mendukung dan sebaliknya. Mantan Menkes(2004-2009) S.F.Supari mengemukakan bahwa Fase sekarang virusnya terus bermutasi jadi vaksin belum diperlukan, Virus yang dilemahkan merupakan bahan vaksin, selama virus bermutasi terus maka sulit ditaklukkan dengan vaksin. benih virus bisa ditemukan bila pandemi mereda Indonesia tidak tepat menggunakan Vaksin-Sinovac-China sebab vaksin memicu terbentuknya antibodi sesuai antigen(attenuated virus). Vaksin buatan Indonesia dengan benih varian dari tanah air lebih cocok, diproses komposisi halal (Saputra,2021); c) Penyaluran vaksin covid-19. (Carolina, 2021). Perihal pendistribusian ini juga dikeluhkan gub. Jateng Pak Ganjar Pranowo, berpendapat bahwa tidak adil jika syarat masuk mall harus sudah vaksin karena jauhnya jumlah ketersediaan vaksin dimasyarakat dibanding kebutuhan. Seharusnya yang belum divaksin juga mempunyai akses yang sama dengan yang divaksin, Selain kesiapan vaksin hal ini juga berkaitan dengan proses pemerataan-penyaluran vaksin.

Menilik kesimpulan survei "Charta Politika” kendala-vaksinasi bisa dilihat pada diagram:

Diagram 1: Kendala dalam melakukan Vaksinasi

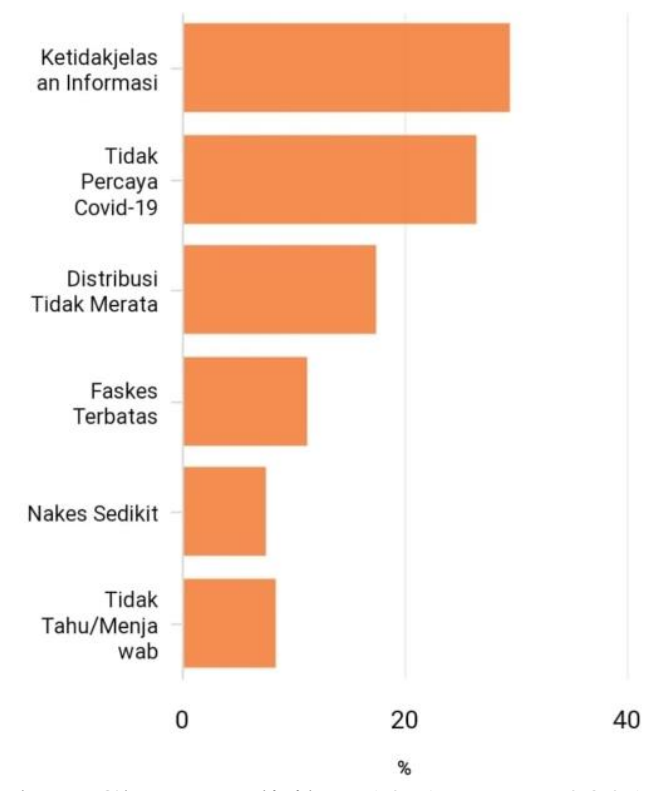

Sumber: Charta Politika, 12 Agustus 2021

Di sisi lain Negara telah menjalankan kewenangan dalam berhubungan dengan rakyatnya, agar tercipta harmonisasi diperlukan adanya norma yang berkesinambungan sehingga perilaku masyarakat di dalam kepatuhan melaksanakan yang menjadi keharusan warga negara dapat ditaati oleh masyarakat. Hal ini memperlihatkan perlindungan negara terhadap warga negaranya. 


\section{KESIMPULAN DAN SARAN \\ Kesimpulan}

Sifat pemberian vaksin kepada masyarakat bersifat memaksa, hal ini diatur secara tegas di dalam Peraturan perundang-undangan terkait. Sehubungan dengan pandemi global cov-19 memposisikan Indonesia sebagai negara kedaruratan kesehatan, hak untuk memilih kesehatan tersebut terbatas sifatnya dengan menghargai hak orang lain artinya sifat pemberian vaksin kepada masyarakat menurut perundang-undangan terkait bersifat memaksa. Kata memaksa ini diartikan sebagai keharusan dan kewajiban yang harus diikuti sebagai warga negara. Sehubungan dengan pandemi global covid-19 memposisikan Indonesia sebagai negara kedaruratan kesehatan maka hak untuk memilih kesehatan tersebut terbatas sifatnya. Setiap orang berhak untuk mendapatkan vaksin yang divasilitasi oleh negara dan negara juga memberikan sanksi kepada masyarakat jika tidak patuh aturan mengenai vaksinasi.

Faktor-faktor yang dihadapi dalam menangani pelaksanaan vaksinasi di masyarakat, ketersedian vaksin; ada yang mendukung ada yang antipati dari masyarakat terkait pelaksanaan vaksinasi; penyaluran yang tidak merata, penyebaran informasi yang tidak utuh menyeluruh sehingga terjadi pro-kontra dalam masyarakat. Dilihat dari diagram "Charta Politika" kendala vaksinasi terbagi menjadi 2 sisi yaitu dari sisi pemerintah dan sisi masyarakat. Dari sisi pemerintah yang utama faktor ketidakjelasan informasi, disusul distribusi tidak merata, fasker terbatas, nakes sedikit. Dari sisi masyarakat disimpulkan hanya satu faktor yaitu tidak percaya Covid-19.

\section{Saran}

Pelaksanaan peraturan perundang-undangan yang berlaku pada masa pandemi yaitu UU 4/1984 dan UU 6/2018 harus diimbangi dengan penerapan norma kesusilaan dalam masyarakat, agar tercapai tujuan dan kepentingan bersama sehingga tercipta harmonisasi kehidupan. Kalaupun terjadi pelanggaran oleh masyarakat dalam menjalankan aturan yang ditetapkan oleh pemerintah, maka upaya persuasif harus diutamakan juga adanya penerapan hukum yang adil dan berimbang sama rata sama rasa. Penulis menyarankan agar komunikasi dimasa krisis tidak hanya mengandalkan media digital, namun juga mengoptimalkan jalur komunikasi konvensional, misalkan media masa, Dengan memberdayakan orang-orang disekitar masyarakat penyampaian pesan pemerintah lebih mudah diterima dan dimengerti karena mereka dalam norma kultur yang sama. Sehingga apa yang menjadi harapan pemerintah dalam menghadapi pandemi mudah dipahami masyarakat dan tercapai tujuan untuk kepentingan bersama. Kesadaran diri dari masyasrakat Indonesia harus terus ditingkatkan agar tidak menjadi kendala dalam mewujudkan tatanan kehidupan baru dalam berbangsa dan bernegara.

Selayaknya pemerintah menyediakan pilihan jenis vaksin yang sesuai dengan karakteristik tubuh komorbid, untuk meminimalisir dampak yang ditimbulkan dari vaksin begitupula bagi penyintas cov-19. Untuk melindungi diri tidak bisa hanya dengan menerima vaksinasi dan menjalankan protokol kesehatan,juga diperlukan istirahat yang cukup, makanan yang sehat bergizi agar imun stabil. Untuk kebijakan yang ditempuh pemerintah juga harus mempertimbangkan segi perekonomian karena banyaknya PHK dan perusahaan yang bangkrut selama hampir 2 tahun pandemi cov-19. Jadi kebijakan dalam menjalankan roda perekonomian harus dipertimbangkan dalam membuat kebijakan yang berhubungan dengan penanggulangan cov-19. Pemerintah selayaknya mendukung penuh vaksin Nusantara dan vaksin Merah Putih yang dikembangkan para peneliti Indonesia.

\section{Ucapan Terima Kasih}

Dosen Pak Yuwono Prianto, S.H.,M.H. sebagai dosen pembimbing. 


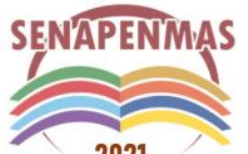

2021
Seminar Nasional Hasil Penelitian dan Pengabdian Kepada Masyarakat 2021 Pengembangan Ekonomi Bangsa Melalui Inovasi Digital Hasil Penelitian dan Pengabdian Kepada Masyarakat Jakarta, 21 Oktober 2021

\section{REFERENSI}

Saputra,R. (2021). “Aneh! Siti Fadilah curiga vaksn masih jalan walau virus terus mutasi.” 19 Juli https://today.line.me/id/v2/article/IDyEBG

Carolina, M. (2021). "Buletin APBN". Pusat Kajian Anggaran/Badan Keahlian DPRRI. Vol.VI, Edisi 4, Maret.

Farisa, FC. (2021). "Jalan Panjang Vaksin Covid-19 Sinovac di RI: Dari Uji Klinis hingga Dapat Izin Penggunaan”. Nasiona. Kompas.com. 12 Januari. https://nasional.kompas.com/read/2021/01/12/08364271/jalan-panjang-vaksin-covid-19sinovac-di-ri-dari-uji-klinis-hinggadapat?utm source=Whatsapp\&utm medium=Refferal\&utm campaign=Sticky Mobile

Gandryani, F. \& Hadi,F. (2021). "Pelaksanaan Vaksinasi Covid-19 Di Indonesia: Hak atau Kewajiban Warga Negara". Jurnal RechtsVinding, 10 (1), 2-3.

Harahap, RJT. (2020). Karakteristik Klinis Penyakit Coronavirus 2019. Jurnal Penelitian Perawat Profesional. Vol.2 No.3.

Indonesia, Perpres. (2021). Peraturan Presiden Republik Indonesia Nomor 14 Tahun 2021 tentang pengadaan Vaksin dan Pelaksanaan Vaksinasi Dalam Rangka Penanggulangan Pandemi Corona Virus Disease 2019 (Covid-19). Cet.2.: Eko Jaya

Indonesia, Keppres (2020). Keputusan Presiden Republik Indonesia Nomor 11 Tahun 2020 tentang Penetapan Kedaruratan Kesehatan Masyarakat Corona Virus Disease 2019 (Covid-19). LN No.66, 2021.

Indonesia, PP (2020). Peraturan Pemerintah Nomor 21 Tahun 2020 tentang Pembatasan Sosial Berskala Besar dalam Rangka Percepatan Penanganan Corona Virus Disease 2019 (Covid-19). LN No.91, 2020.

Indonesia, UU. (1945).’Undang-Undang Dasar (UUD) Tahun 1945 dan Amandemen tentang UUD 1945 dan Amandemen".

Indonesia, UU (1984). Undang-Undang Nomor 4 Tahun 1984 tentang Wabah Penyakit Menular. LN No. 20, 1984.

Indonesia, UU (2018). Undang-Undang Nomor 6 Tahun 2018 tentang Kekarantinaan Kesehatan. LN No.128, 2018.

Jayani, DH. (2020)."Asal Usul Virus Corona Masuk Ke Indonesia”. 22 Mei https://katadata.co.id/timdatajournalism/analisisdata/5ecb63ef78264/asal-usul-virus-coronamasuk-ke-indonesia

Jayani, DH.(2021). "Ini Sederet Kendala Yang Hambat Vaksinasi Covid-19 di Indonesia". katadata.co.id, 12 Agustus.

Mahkamah Konstitusi.(2016). Modul Pendidikan Negara Hukum Dan Demokrasi. Pusat Pendidikan Pancasila dan Konstitusi, Jakarta.

Noveria, CAP (2021). "RI Sudah Impor 143 Juta Dosis Vaksin Paling Banyak Sinovac". 21 Juli https://www.google.com/amp/s/www.cnbcindonesia.com/news/20210721171151-4262560/ri-sudah-impor-143-juta-dosis-vaksin-paling-banyak-sinovac/amp

Sidharta dan Petrus Lakonawa. (2018). "Lex Specialis Derogat Legi Generali: Makna dan Penggunaannya". Binus University, Maret. https://businesslaw.binus.ac.id/2018/03/03/lex-specialis-derogat-legi-generali/

Soerjono,S \& Mamudji, S (2021). "Penelitian Hukum Normatif Suatu Tinjauan Singkat. RajaGrafindo Persada, Depok.

Suharso \& Retnoningsih, A. (2014). Kamus Besar Bahasa Indonesia. Widya Karya, Semarang.

Wuragil, Z. (2020). "Indonesia Setor 13 Data Genom Virus Corona Covid-19". Tempo.co, 11 mei.https://tekno.tempo.co/read/1340825/indonesia-setor-data-13-genom-virus-corona-covid$\underline{19}$ 
(halaman kosong) 